\title{
ANALISIS KEKERINGAN HIDROLOGI BERDASARKAN STANDARDIZED PRECIPITATION INDEX (SPI) DI DAERAH ALIRAN SUNGAI TIRTOMOYO KABUPATEN WONOGIRI
}

\author{
Warakesthi Rahayu Wicaksanti ${ }^{1)}$, Rr. Rintis Hadiani ${ }^{2)}$, Setiono ${ }^{3)}$ \\ 1) Mahasiswa Fakultas Teknik, Prodi Teknik Sipil, Universitas Sebelas Maret \\ 2) Pengajar Fakultas Teknik, Prodi Teknik Sipil, Universitas Sebelas Maret \\ 3) Pengajar Fakultas Teknik, Prodi Teknik Sipil, Universitas Sebelas Maret \\ Jl. Ir. Sutami 36A, Surakarta 57126; Telp. 0271-634524. Email:
}

\begin{abstract}
Tirtomoyo Watershed is an area which has lime soil susceptible to drought. So, it is necessary to know it's characteristics early. The purpose of this research is to analyze hydrological drought by calculating index of drought and monthly water discharge connected to drought prediction. Index of drought is used for drought criteria mapping.

This the rainfall data were taken from 2008-2017. Index of drought were analyzed by using Standardized Precipitation Index (SPI) Method. SPI Method is index method which is used to decide high deviation of rain to normal condition in long period of rain. While, monthly water discharge were analyzed by using Global Rainfall-Runoff Model (GR2M) Method. Drought Index value and water discharge were connected on a chart. The chart purpose is to calculating monthly water discharge based on drought index value. While, classification of SPI index used for mapping the speard of drought criteria using software ArcGIS.

The result of analysis obtained that drought index SPI the lowest index (-1,71) with very dry criteria on August 2016 and the highest drought index is 2,19 with very wet criteria on December 2014. While, the lowest monthly water discharge $\left(0,002 \mathrm{~m}^{3} / \mathrm{sec}\right)$ on November 2008 and the bighest monthly water discharge is $0,426 \mathrm{~m}^{3} / \mathrm{sec}$ on February 2009. From the graphic connection of drought index SPI and monthly water discharge, obtained that graphic with a linear equations $y=0,0993 x+0,1186$, with $y$ as water discharge and $x$ as SPI drought index. Then, for mapping the speard of drought criteria obtained that the drought were not happened on 2008, 2009, and 2015, but the worst drought were happened on August 2016.
\end{abstract}

Key words: Drought, Water Discharge, Standardized Precipitation Index (SPI), Global Rainfall-Runoff Model (GR2M), Conection of SPI Index and Water Discharge GR2M.

\begin{abstract}
Abstrak
Daerah Aliran Sungai (DAS) Tirtomoyo merupakan daerah yang memiliki tanah berjenis kapur yang rentan terhadap bencana kekeringan ketika musim kemarau. Untuk mengurangi dampak kekeringan, maka perlu mengenali karakteristiknya lebih awal. Penelitian ini bertujuan untuk menganalisis kekeringan hidrologi dengan menghitung indeks kekeringan dan debit bulanan yang kemudian dihubungkan untuk mendapatkan prediksi kekeringan. Indeks kekeringan digunakan untuk pemetaan kriteria kekeringan.

Penelitian kekeringan ini dilakukan pada tahun 2008-2017. Indeks kekeringan dianalisis dengan Metode Standardized Precipitation Index (SPI). Metode SPI merupakan metode indeks yang digunakan untuk menentukan penyimpangan tinggi hujan terhadap kondisi normalnya dalam satu periode yang panjang. Sedangkan debit bulanan dianalisis dengan Metode Global Rainfall-Runoff Model (GR2M). Nilai indeks kekeringan dan debit bulanan dihubungkan kedalam sebuah grafik. Grafik hubungan ini bertujuan untuk menghitung debit bulanan dengan berdasarkan nilai indeks yang didapatkan. Selain itu, klasifikasi dari indeks kekeringan SPI digunakan untuk pemetaan persebaran kriteria kekeringan dengan menggunakan software ArcGIS.

Hasil analisis diperoleh nilai indeks kekeringan SPI terkecil yaitu -1,71 dengan kriteria sangat kering pada Agustus 2016 dan indeks terbesar yaitu 2,19 dengan kriteria amat sangat basah pada Desember 2014. Sedangkan debit bulanan GR2M terkecil diperoleh $0,002 \mathrm{~m}^{3} /$ detik pada November 2008 dan debit bulanan terbesar 0,426 $\mathrm{m}^{3} /$ detik pada Februari 2009. Dari grafik hubungan indeks kekeringan SPI dengan debit bulanan diperoleh grafik linier dengan persamaan $\mathrm{y}=0,0993 x+0,1186$, dengan $y$ adalah debit bulanan GR2M dan $x$ adalah indeks kekeringan SPI. Kemudian untuk pemeteaan persebaran kriteria kekeringan diperoleh bahwa kekeringan tidak terjadi pada tahun 2008, 2009 dan 2015, namun kekeringan terparah terjadi pada Agustus 2016.
\end{abstract}

Kata kunci: Kekeringan, Debit Bulanan, Standardized Precipitation Index (SPI), Global Rainfall-Runoff Model (GR2M), Hubungan Indeks SPI dengan Debit GR2M.

\section{PENDAHULUAN}

Saat ini terjadi pergeseran iklim yang mengakibatkan ketidakseimbangan durasi antara musim penghujan dan musim kemarau. Salah satu akibatnya yaitu terjadi kemarau berkepanjangan yang dapat menyebabkan kekeringan pada beberapa daerah di Indonesia. Salah satu daerah yang berpotensi terjadi bencana kekeringan adalah Kabupaten Wonogiri. Sebagian besar daerah Wonogiri memiliki tanah berjenis kapur. Hal ini menyebabkan kesulitan dalam menyerapkan air ke dalam tanah. 
Kekeringan memiliki dampak yang luas, diantaranya adalah kurangnya sumber air minum, kurangnya sumber air untuk memenuhi kebutuhan sehari-hari, banyaknya tanaman yang akan mati dan timbul banyak bibit penyakit. Menurut Rr. Rintis Hadiani (2009), kekeringan dapat menimbulkan kekurangan lahan pekerjaan bagi masyarakat petani, sehingga bahan pangan yang dihasilkan dan penghasilan masyarakat cenderung menurun. Oleh sebab itu, perlu dilakukan analisis kekeringan untuk mengenali karakteristik kekeringan lebih awal. Hal ini bertujuan untuk mengurangi dampak-dampak kekeringan tersebut.

Penelitian ini, analisis kekeringan dilakukan dengan metode Standardized Precipitation Index (SPI). Analisis SPI dapat menghitung indeks kekeringan dan menggambarkan tingkat kekeringan meteorologi pada suatu daerah. Sedangkan untuk kondisi hidrologi yakni ketersediaan air, dihitung dengan metode Global Rainfall-Runoff Model (GR2M). Dari hasil perhitungan indeks SPI dan debit GR2M akan dihubungkan ke dalam sebuah grafik. Selain itu, dari hasil indeks SPI digunakan untuk pemetaan persebaran krteria kekeringan.

\section{LANDASAN TEORI}

\section{Dasar Teori}

\section{Pengisian Data Hujan yang Hilang}

Pada analisis perhitungan indeks kekeringan dan debit memerlukan data hujan yang lengkap. Sedangkan dalam pengukuran curah hujan sering mengalami masalah seperti tidak tercatatnya data hujan. Maka perlu dilakukan pengisian data hujan yang hilang tersebut. Ada beberapa metode yang dapat digunakan dalam pengisian data hujan yang hilang, salah satunya Reciprocal Method. Metode ini merupakan metode pengisian data hujan dengan memperhitungkan jarak dan curah hujan dari stasiun hujan yang terdekat. Pengisian data hujan yang hilang dengan Reciprocal Method dapat dihitung dengan Persamaan 1.

$P_{x}=\frac{\sum_{i=1}^{n} \frac{P_{i}}{L_{i}{ }^{2}}}{\sum_{i=1}^{n} \frac{1}{L_{i}{ }^{2}}}$

dengan :

$P_{x}=$ Data hujan yang hilang di stasiun $\mathrm{X}(\mathrm{mm})$,

$P_{i}=$ Data hujan di stasiun sekitarnya pada periode yang sama $(\mathrm{mm})$,

$L_{i}=$ Jarak stasiun $\mathrm{X}$ dengan stasiun sekitarnya $(\mathrm{km})$,

$n=$ Jumlah stasiun hujan di sekitarnya.

\section{Pemeriksaan Kepanggahan Data}

Pada penelitian ini, pemeriksaaan kepanggahan dilakukan dengan metode Rescaled Adjusted Partial Sums (RAPS). Pemerikasaan kepanggahan dilakukan dengan tujuan untuk mendeteksi penyimpangan data hujan dan memastikan data hujan yang dipakai panggah atau tidak. Menurut Sri Harto (1993), metode RAPS merupakan pengujian konsistensi dengan menggunakan data dari stasiun itu sendiri yaitu pengujian dengan komulatif penyimpangan terhadap nilai rata-rata dibagi dengan akar komulatif rerata penyimpangan kuadrat terhadap nilai reratanya.

Pemerikasaan kepanggahan data dengan metode RAPS dapat dihitung dengan Persamaan 4.

$S_{k}^{*}=\sum_{i=1}^{k}\left(Y_{i}-\bar{Y}\right)$,dengan $\mathrm{k}=1,2,3, \ldots, \mathrm{n}$

$S_{k}^{*}=0$.

$S_{k}^{* *}=\frac{S_{k}^{*}}{D_{y}}$,dengan $\mathrm{k}=0,1,2,3, \ldots, \mathrm{n}$

$D_{y}^{2}=\sum_{i=1}^{n} \frac{\left(Y_{i}-\bar{Y}\right)^{2}}{n}$

dengan :

$Y_{i} \quad=$ Data hujan ke-i,

$\bar{Y} \quad=$ Data hujan rerata ke-i,

$D_{y} \quad=$ Standar deviasi,

$n \quad=$ Jumlah data.

Untuk uji kepanggahan digunakan statistik dengan Persamaan 6 - Persamaan 7.

$Q=$ maksimum $\left|S_{k}^{* *}\right|$ dengan $0 \leq k \leq n$, atau 
Bila $Q / \sqrt{n}$ yang didapatkan lebih kecil dari nilai kritik untuk tahun dan confidence level yang sesuai, maka data dinyatakan panggah (Harto, 1993).

Nilai kritik Q dan R ditunjukkan dalam Tabel 1 berikut :

Tabel 1 Nilai Kritik Q dan R

\begin{tabular}{|c|c|c|c|c|c|c|}
\hline \multirow[t]{2}{*}{$\mathbf{n}$} & \multicolumn{3}{|c|}{$\frac{Q}{\sqrt{n}}$} & \multicolumn{3}{|c|}{$\frac{R}{\sqrt{n}}$} \\
\hline & $90 \%$ & $95 \%$ & $99 \%$ & $90 \%$ & $95 \%$ & $99 \%$ \\
\hline 10 & 1,05 & 1,14 & 1,29 & 1,21 & 1,28 & 1,38 \\
\hline 20 & 1,10 & 1,22 & 1,42 & 1,34 & 1,43 & 1,60 \\
\hline 30 & 1,12 & 1,24 & 1,46 & 1,40 & 1,50 & 1,70 \\
\hline 40 & 1,13 & 1,26 & 1,50 & 1,42 & 1,53 & 1,74 \\
\hline 50 & 1,14 & 1,27 & 1,52 & 1,44 & 1,55 & 1,78 \\
\hline 100 & 1,17 & 1,29 & 1,55 & 1,50 & 1,62 & 1,86 \\
\hline 500 & 1,22 & 1,36 & 1,63 & 1,62 & 1,75 & 2,00 \\
\hline
\end{tabular}

(Sumber : Sri Harto, 1993)

\section{Hujan Wilayah Bulanan}

Pada penelitian ini hujan wilayah bulanan dihitung dengan metode Poligon Thiessen. Metode Poligon Thiessen memperhitungkan bobot masing-masing stasiun hujan yang mewakili luasan di sekitarnya. Pada suatu luasan di dalam DAS dianggap bahwa hujan adalah sama dengan yang terjadi pada stasiun yang terdekat, sehingga hujan yang tercatat pada stasiun tersebut mewakili hujan pada luasan tersebut (Bambang Triatmodjo, 2010).

Hujan wilayah bulanan dapat dihitung dengan Persamaan 8.

$p=\frac{A_{1} \cdot d_{1}+A_{2} \cdot d_{2}+\cdots A_{n} \cdot d_{n}}{A}=\sum_{i=1}^{n} \frac{A_{i} \cdot d_{l}}{A}$.

dengan :

$A \quad=$ Luas area total $\quad\left(\mathrm{km}^{2}\right)$,

$p \quad=$ Tinggi hujan rata-rata area $\quad(\mathrm{mm})$,

$d_{1}, d_{2}, \ldots d_{n}=$ Tinggi hujan di pos $1,2, \ldots \mathrm{n} \quad(\mathrm{mm})$,

$A_{1}, A_{2}, \ldots A_{n}=$ Luas daerah pengaruh pos $1,2, \ldots \mathrm{n} \quad(\mathrm{km} 2)$.

\section{Evapotranspirasi}

Evapotranspirasi merupakan evaporasi dari permukaan lahan yang ditumbuhi tanaman. Pada penelitian ini, untuk menghitung besarnya evapotranspirasi menggunakan metode Penman-Monteith. Dalam proses perhitungan evapotranspirasi menurut metode Penman-Monteith memerlukan data dan letak stasiun klimatologi sebagai berikut (SNI 7745:2012). Evapotranspirasi dapat dihitung dengan Persamaan 9.

$E T_{O}=\frac{0,408 \Delta R_{n}+\gamma \frac{900}{(T+273)} U_{2}\left(e_{s}-e_{a}\right)}{\Delta+\gamma\left(1+0,34 U_{2}\right)}$

dengan:

$E T_{O}=$ Evapotranspirasi tanaman acuan

(mm/hari),

$R_{n} \quad=$ Radiasi matahari netto di atas permukaan tanaman

$\left(\mathrm{MJ} / \mathrm{m}^{2} /\right.$ hari)

$T \quad=$ Suhu udara rata-rata

$\left({ }^{\circ} \mathrm{C}\right)$

$U_{2} \quad=$ Kecepatan angin pada ketinggian $2 \mathrm{~m}$ di atas permukaan tanah $(\mathrm{m} / \mathrm{s})$,

$e_{s} \quad=$ Tekanan uap air jenuh

$(\mathrm{kPa})$,

$e_{a} \quad=$ Tekanan uap air aktual

$(\mathrm{kPa})$,

$\Delta \quad=$ Kemiringan kurva tekanan uap air terhadap suhu

$\left(\mathrm{kPa} /{ }^{\circ} \mathrm{C}\right)$,

$\gamma \quad=$ Konstanta psikrometrik $\left(\mathrm{kPa} /{ }^{\circ} \mathrm{C}\right)$. 


\section{Analisis Debit Bulanan}

Dalam analisis debit bulanan dapat dihitung dengan menggunakan model neraca air (water balance). Analisis debit bulanan pada penelitian ini menggunakan salah satu model neraca air yaitu dengan menggunakan Global RainfallRunoff Model (GR2M). Menurut Perrin et al., 2007, metode GR2M merupakan model aliran hujan global dengan dua parameter. Model konseptual GR2M memiliki struktur yang bersifat empiris dan menggabungkan reservoir produksi dan reservoir routing. Metode GR2M telah mengenal beberapa versi, berturut-turut diusulkan oleh Kabouya (1990), kabouya dan Michel (1991), Makhlouf (1994), Makhlouf dan Michel (1994), Mouelhi (2003) dan Mouelhi et al (2006b), yang secara bertahap memperbaiki kiberja model. Versi dari Mouelhi et al (2006b) yang nampaknya lebih efisien (Perrin et al., 2007).

Metode GR2M versi Mouelhi et al (2006) mengikuti kelembaban tanah DAS untuk mempertimbangkan keadaan lembah sungai sebelumnya dengan menggunakan dua fungsi, yaitu:

1. Fungsi produksi digunakan untuk perhitungan kelembaban tanah (SMC) dan fungsi pertukaran air.

2. Fungsi transfer hanya menggunakan quadratic routing store (kapasitas yang ditentukan $=60 \mathrm{~mm}$ )

Model GR2M memiliki 2 parameter yang dapat dioptimalkan, yaitu (Perrin et al.,2007) :

$\mathrm{X} 1=$ Kapasitas simpanan kelembaban tanah (SMC),

$\mathrm{X} 2=$ Koefisien penyebaran air tanah.

Nilai parameter kalibrasi GR2M yang diperoleh dari daerah aliran sungai yang besar dapat dilihat pada Tabel 2.

Tabel 2. Nilai Parameter Kalibrasi GR2M

\begin{tabular}{ccc}
\hline Parameter & Rata - Rata & Interval pada Kepercayaan $\mathbf{9 0 \%}$ \\
\hline $\mathrm{X} 1(\mathrm{~mm})$ & 380 & $140-640$ \\
\hline $\mathrm{X} 2$ & 0,92 & $0,21-1,31$ \\
\hline
\end{tabular}

(Sumber : Perrin et al., 2007)
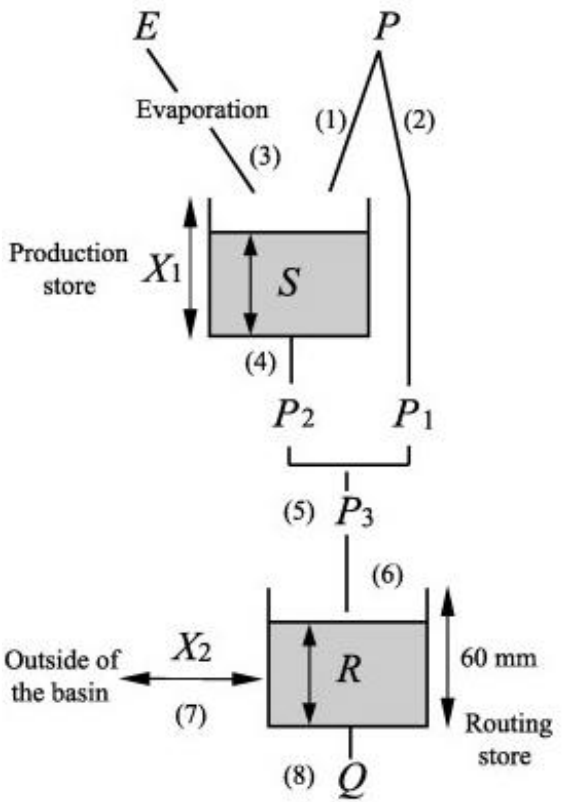

Gambar 1. Konsep Metode GR2M (Mouelhi et al., 2006)

Persamaan yang digunakan oleh metode GR2M Persamaan 10 - Persamaan 19.

1. $S_{1}=\frac{S_{0}+X_{1} \varphi}{1+\varphi \frac{S_{0}}{X_{1}}}$ dengan $\varphi=\tanh \frac{P}{X_{1}}$

2. $P_{1}=P+S_{0}-S_{1}$ 
3. $S_{2}=\frac{S_{1}(1-\psi)}{1+\psi\left(1-\frac{S_{1}}{X_{1}}\right)}$ dengan $\psi=\tanh \frac{E}{X_{1}}$

4. $S_{a}=\frac{S_{2}}{\left(1+\left(\frac{S_{2}}{X_{1}}\right)^{3}\right)^{1 / 3}}$

5. $\quad P_{2}=S_{2}-S_{a}$

6. $P_{3}=P_{1}+P_{2}$

7. $R_{1}=R_{0}+P_{3}$

8. $R_{2}=X_{2} \cdot R_{1}$

9. $Q=\frac{R_{2}^{2}}{R_{2}+60}$.

10. $R=R^{2}-Q$

dengan:

$S \quad=$ Kelengasan awal tanah $\quad(\mathrm{mm})$,

$S_{1}=$ Kelengasan tanah akibat presipitasi (mm),

$S_{2} \quad=$ Kelengasan tanah akibat presipitasi dan evapotranspirasi ( $\mathrm{mm}$ ),

$S_{a} \quad=$ Kelengasan tanah akibat infiltrasi ke lapisan tanah $\quad(\mathrm{mm})$,

$P \quad=$ Tinggi hujan bulanan (mm),

$P_{1}=$ Aliran permukaan (mm),

$P_{2} \quad=$ Kedalaman hujan akibat pengurangan $S_{2}-S_{a} \quad$ (mm),

$P_{3} \quad=$ Kedalaman hujan total $\left(P_{1}+P_{2}\right) \quad$ (mm),

$X_{1}=$ Kelengasan maksimum tanah $\quad(\mathrm{mm})$,

$E \quad=$ Evapotranspirasi $\quad(\mathrm{mm})$,

$R \quad=$ Nilai routing $\quad(\mathrm{mm})$,

$Q \quad=$ Debit runoff $\quad(\mathrm{mm})$.

\section{Standardized Precipitation Index (SPI)}

Standardized Precipitation Index (SPI) merupakan salah satu metode perhitungan indeks kekeringan dan untuk mengevaluasi tingkat kekeringan berdasar nilai klasifikasi tingkat kekeringannya (McKee et al, 1993). SPI bertujuan untuk mengetahui dan memonitor kekeringan. Defisit tinggi hujan atau dalam kondisi kekeringan terjadi pada saat nilai SPI bernilai negatif satu (-1) atau lebih kecil. Hal ini didasari dengan menurunnya tinggi hujan yang mengakibatkan kandungan air dalam tanah dan debit berkurang.

Kelebihan metode SPI yaitu metode sederhana yang hanya membutuhkan data tinggi hujan. Sedangkan kelemahannya yaitu data tinggi hujan menggunakan seri waktu yang panjang dan handal. Selain itu, metode SPI hanya dapat menjelaskan kekeringan meteorologi (Nofriyadi Widodo, 2013).

Indeks kekeringan SPI dapat dihitung dengan Persamaan 20.

$Z_{i j}=\frac{X_{i j}-\bar{X}_{j}}{\sigma_{j}}$

dengan :

$Z_{i j} \quad=$ Indeks kekeringan, bulan ke-i tahun ke-j,

$X_{i j} \quad=$ hujan bulanan bulan ke-I tahun ke-j,

$\bar{X}_{j} \quad=$ hujan tahun j, rata-rata,

$\sigma_{j} \quad=$ simpangan baku tahun $\mathrm{j}$.

Dengan simpangan baku seperti Pesamaan 21.

$\sigma=\sqrt{\frac{(x-\bar{x})^{2}}{n-1}}$

dengan :

$x=$ data tinggi hujan, 
$\bar{x}=$ jumlah rata-rata tinggi hujan,

$n=$ jumlah data. 
Tabel 3 Klasifikasi Nilai SPI

\begin{tabular}{cc}
\hline Nilai & Klasifikasi \\
\hline 2,00 & Amat Sangat Basah \\
\hline $1,50-1,99$ & Sangat Basah \\
\hline $1,00-1,49$ & Basah \\
\hline$(-0,99)-(0,99)$ & Normal \\
\hline$(-1,00)-(-1,49)$ & Kering \\
\hline$(-1,50)-(-1,99)$ & Sangat Kering \\
\hline$>(-2,00)$ & Amat Sangat Kering
\end{tabular}

(Sumber : World Meteorological Organization, 2012)

\section{METODE PENELITIAN}

Penelitian ini dilakukan di Daerah Aliran Sungai Tirtomoyo yang terletak di Kabupaten Wonogiri, Jawa Tengah. Daerah aliran sungai Tirtomoyo masuk ke dalam daerah aliran sungai Bengawan Solo yang memiliki luas 202,56 $\mathrm{km}^{2}$. Data yang digunakan dalam penelitian ini adalah data sekunder. Adapun data-data yang diperlukan adalah peta DAS Tirtomoyo, data curah hujan pada stasiun hujan Balong, Watugede dan Puter, data klimatologi waduk ngancar, dan data debit lapangan di DAS Tirtomoyo. Tahapan yang dilakukan dalam penelitian ini yaitu pengumpulan data, pengisian data hujan yang hilang, uji kepanggahan data, perhitungan hujan wilayah bulanan, perhitungan evapotranspirasi, perhitungan debit bulanan, perhitungan indeks kekeringan, dan pemetaan kriteria kekeringan.

\section{HASIL DAN PEMBAHASAN}

\section{Perhitungan Hujan Wilayah Bulanan}

Perhitungan hujan wilayah bulanan dalam penelitian ini menggunakan metode Poligon Thiessen. Poligon Thiessen pada penelitian ini dianalisis menggunakan software ArcGIS, dengan tiga stasiun hujan yaitu stasiun Balong (131d), Watugede (115d), dan Puter (115c). Dari Poligon Thiessen dapat dihitung luas daerah tangkapan hujan setiap pos stasiun hujan.

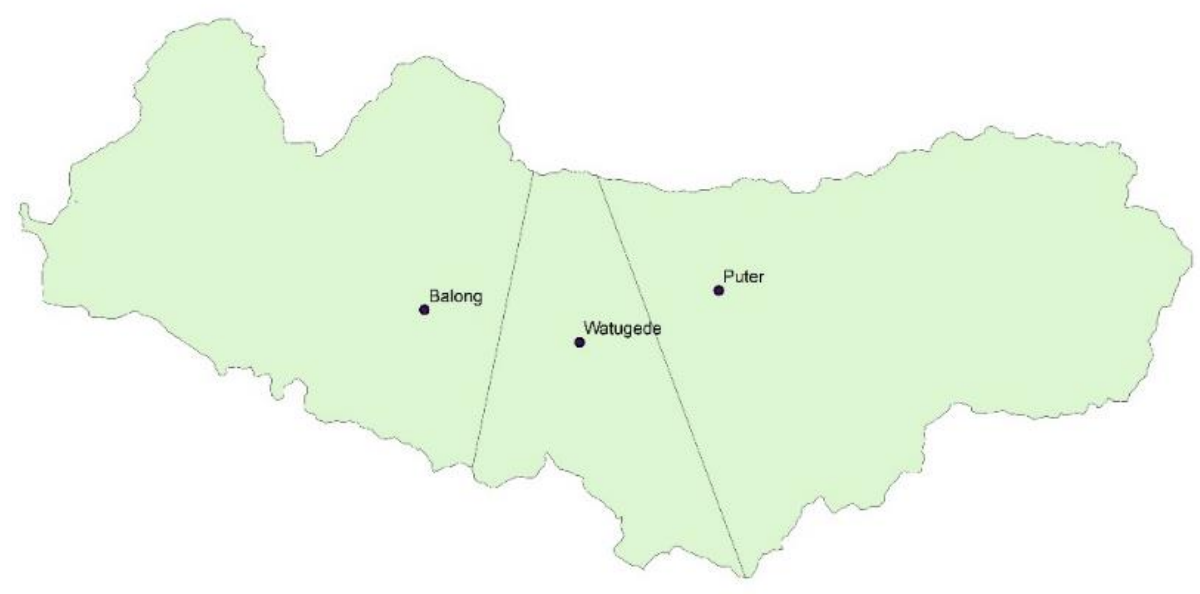

Gambar 2. Poligon Thiessen DAS Tirtomoyo (Analisis dengan Software ArcGIS)

Luas daerah tangkapan hujan pada setiap stasiun pos stasiun hujan adalah :

Stasiun Hujan Puter (115c) $\quad=89,99 \mathrm{~km}^{2}$

Stasiun Hujan Balong (131d) $\quad=79,73 \mathrm{~km}^{2}$

Stasiun Hujan Watugede $(115 \mathrm{~d})=32,84 \mathrm{~km}^{2}$

DAS Tirtomoyo $\quad=202,56 \mathrm{~km}^{2}$

Perhitungan hujan wilayah bulanan dihitung berdasarkan Persamaan 8. Hasil dari perhitungan disajikan pada Tabel 4. 
Tabel 4. Rekapitulasi Hasil Perhitungan Hujan Wilayah Bulanan (mm/bulan)

\begin{tabular}{ccccccccccccc}
\hline Tahun & Jan & Feb & Mar & Apr & Mei & Jun & Jul & Augt & Sept & Okt & Nov & Des \\
\hline $\mathbf{2 0 0 8}$ & 318,52 & 409,95 & 344,26 & 172,13 & 5,20 & 0,00 & 0,00 & 0,00 & 0,00 & 0,00 & 0,00 & 215,07 \\
\hline $\mathbf{2 0 0 9}$ & 378,13 & 476,47 & 184,10 & 174,52 & 210,70 & 71,83 & 0,00 & 0,00 & 0,00 & 0,00 & 186,32 & 121,69 \\
\hline $\mathbf{2 0 1 0}$ & 281,01 & 355,56 & 614,32 & 133,82 & 223,50 & 102,83 & 35,99 & 26,98 & 264,41 & 445,26 & 0,00 & 365,60 \\
\hline $\mathbf{2 0 1 1}$ & 327,21 & 123,06 & 449,05 & 305,23 & 290,42 & 23,45 & 0,65 & 0,65 & 0,00 & 63,73 & 367,27 & 474,90 \\
\hline $\mathbf{2 0 1 2}$ & 406,21 & 409,64 & 565,88 & 237,52 & 135,61 & 26,78 & 0,00 & 0,00 & 0,00 & 35,32 & 284,18 & 443,86 \\
\hline $\mathbf{2 0 1 3}$ & 444,47 & 426,56 & 148,76 & 298,19 & 151,52 & 250,73 & 71,99 & 0,00 & 0,00 & 93,36 & 186,54 & 443,74 \\
\hline $\mathbf{2 0 1 4}$ & 369,64 & 240,06 & 183,91 & 188,60 & 71,27 & 114,12 & 28,52 & 0,00 & 0,00 & 0,00 & 293,22 & 541,69 \\
\hline $\mathbf{2 0 1 5}$ & 456,47 & 434,11 & 399,25 & 436,16 & 94,78 & 10,63 & 0,00 & 0,00 & 0,00 & 0,00 & 170,06 & 249,75 \\
\hline $\mathbf{2 0 1 6}$ & 329,72 & 409,82 & 314,92 & 297,48 & 154,67 & 141,57 & 166,99 & 76,24 & 297,19 & 400,75 & 451,19 & 311,97 \\
\hline $\mathbf{2 0 1 7}$ & 403,05 & 394,31 & 218,83 & 444,50 & 68,57 & 83,08 & 24,30 & 0,00 & 111,29 & 65,13 & 576,02 & 305,44 \\
\hline
\end{tabular}

\section{Perhitungan Evapotranspirasi}

Perhitungan evapotranspirasi dalam penelitian ini menggunakan software CROPWAT versi 8.0 yang mengacu pada metode Penman-Monteith. Perhitungan evapotranspirasi pada software CROPWAT memerlukan input data klimatologi berupa termperatur, kelembaban udara, kecepatan angin, dan radiasi matahari. Rekapitulasi hasil perhitungan disajikan dalam Tabel 5.

Tabel 5. Rekapitulasi Hasil Perhitungan Evapotranspirasi (mm/bulan)

\begin{tabular}{|c|c|c|c|c|c|c|c|c|c|c|c|c|}
\hline Tahun & Jan & Feb & Mar & Apr & Mei & Jun & Jul & Augt & Sept & Okt & Nov & Des \\
\hline 2008 & 62,00 & 60,03 & 92,69 & 67,20 & 56,42 & 51,60 & 51,77 & 57,97 & 61,80 & 70,37 & 75,90 & 71,30 \\
\hline 2009 & 63,55 & 51,24 & 76,88 & 55,50 & 47,12 & 43,80 & 46,81 & 47,74 & 51,30 & 56,11 & 58,50 & 55,8 \\
\hline 2010 & 62,00 & 51,80 & 77,50 & 54,90 & 48,67 & 43,50 & 50,53 & 50,84 & 52,50 & 55,80 & 60,00 & 63,86 \\
\hline 2011 & 62,31 & 58,52 & 60,45 & 52,20 & 51,77 & 57,60 & 44,64 & 47,74 & 5,60 & 56,11 & 53,40 & 59,52 \\
\hline 2012 & 64,17 & 64,09 & 75,33 & 67,50 & 57,04 & 53,40 & 39,06 & 58,59 & 60,90 & 71,92 & 71,40 & 84,01 \\
\hline 2013 & 71,61 & 136,08 & 101,37 & 60,00 & 58,59 & 53,40 & 48,67 & 52,39 & 51,00 & 61,38 & 58,20 & 63,24 \\
\hline 2014 & 68,20 & 63,00 & 57,66 & 57,30 & 55,49 & 46,50 & 44,95 & 53,01 & 54,00 & 73,78 & 63,60 & 64,17 \\
\hline 2015 & 70,06 & 62,16 & 64,17 & 61,80 & 50,22 & 41,40 & 49,29 & 49,29 & 55,50 & 62,62 & 60,60 & 64,79 \\
\hline 2016 & 109,15 & 92,80 & 102,30 & 102,00 & 92,38 & 83,70 & 80,91 & 95,17 & 97,50 & 94,24 & 91,20 & 88,97 \\
\hline 2017 & 91,45 & 87,64 & 104,47 & 89,40 & 84,63 & 78,60 & 75,33 & 88,66 & 99,00 & 106,95 & 82,20 & 81,22 \\
\hline
\end{tabular}

Perhitungan Debit Bulanan

Perhitungan debit bulanan dalam penelitian ini menggunakan metode Global Rainfall-Runoff Model (GR2M). Perhitungan debit bulanan GR2M dihitung berdasarkan Persamaan 10 - Persamaan 19. Rekapitulasi hasil perhitungan disajikan dalam Tabel 6.

Tabel 6. Rekapitulasi Hasil Perhitungan Debit GR2M (m³/detik)

\begin{tabular}{ccccccccccccc}
\hline Tahun & Jan & Feb & Mar & Apr & Mei & Jun & Jul & Augt & Sept & Okt & Nov & Des \\
\hline 2008 & 0,14 & 0,13 & 0,12 & 0,21 & 0,29 & 0,29 & 0,25 & 0,32 & 0,16 & 0,25 & 0,14 & 0,13 \\
\hline 2009 & 0,25 & 0,30 & 0,21 & 0,09 & 0,29 & 0,27 & 0,16 & 0,31 & 0,24 & 0,25 & 0,25 & 0,30 \\
\hline 2010 & 0,23 & 0,13 & 0,43 & 0,28 & 0,40 & 0,09 & 0,12 & 0,28 & 0,19 & 0,14 & 0,23 & 0,13 \\
\hline 2011 & 0,12 & 0,11 & 0,11 & 0,22 & 0,17 & 0,16 & 0,12 & 0,31 & 0,17 & 0,26 & 0,12 & 0,11 \\
\hline 2012 & 0,03 & 0,13 & 0,14 & 0,20 & 0,10 & 0,10 & 0,06 & 0,09 & 0,09 & 0,06 & 0,03 & 0,13 \\
\hline 2013 & 0,02 & 0,06 & 0,08 & 0,05 & 0,04 & 0,15 & 0,06 & 0,03 & 0,07 & 0,04 & 0,02 & 0,06 \\
\hline 2014 & 0,01 & 0,02 & 0,04 & 0,02 & 0,02 & 0,06 & 0,03 & 0,02 & 0,08 & 0,02 & 0,01 & 0,02 \\
\hline 2015 & 0,01 & 0,01 & 0,02 & 0,01 & 0,01 & 0,02 & 0,01 & 0,01 & 0,04 & 0,01 & 0,01 & 0,01 \\
\hline 2016 & 0,00 & 0,01 & 0,11 & 0,01 & 0,01 & 0,01 & 0,01 & 0,01 & 0,12 & 0,02 & 0,00 & 0,01 \\
\hline
\end{tabular}


Analisis indeks kekeringan pada penelitian ini menggunakan metode Standardized Precipitation Index (SPI). Data yang dibutuhkan adalah curah hujan selama 10 tahun (2008-2017). Perhitungan indeks kekeringan SPI dihitung berdasarkan Persamaan 20 dan pengelompokan kriteria setiap indeks sesuai dengan Tabel 3. Sebagai contoh perhitungan dan kriteria pada tahun 2017 disajikan dalam Tabel 7.

Tabel 7. Rekapitulasi Hasil Perhitungan Indeks Kekeringan

\begin{tabular}{cccc}
\hline Bulan & $\begin{array}{c}\text { Curah Hujan } \\
(\mathbf{m m} / \text { bulan })\end{array}$ & $\begin{array}{c}\text { Indeks } \\
\text { Kekeringan }\end{array}$ & Kriteria \\
\hline Januari & 403.1 & 0.92 & Normal \\
\hline Februari & 394.3 & 0.88 & Normal \\
\hline Maret & 218.8 & -0.03 & Normal \\
\hline April & 444.5 & 1.14 & Basah \\
\hline Mei & 68.6 & -0.81 & Normal \\
\hline Juni & 83.1 & -0.73 & Normal \\
\hline Juli & $\mathbf{2 4 . 3}$ & $\mathbf{- 1 . 0 3}$ & Kering \\
\hline Agstus & $\mathbf{0 . 0}$ & $\mathbf{- 1 . 1 6}$ & Kering \\
\hline September & 111.3 & -0.59 & Normal \\
\hline Oktober & 65.1 & -0.82 & Normal \\
\hline November & 576.0 & 1.82 & Sangat Basah \\
\hline Desember & 305.4 & 0.42 & Normal \\
\hline Rerata Hujan & 224,5 & & \\
\hline Simpangan Baku & 193,60 & & \\
\hline
\end{tabular}

\section{Hubungan Debit Bulanan GR2M dan Index Kekeringan SPI}

Hubungan indeks kekeringan SPI dan debit bulanan didapatkan rentang nilai debit yang sesuai dengan kriteria kekeringan yaitu kriteria sangat kering adalah $\leq 0,010 \mathrm{~m} 3 /$ detik, kriteria kering adalah $0,011-0,044 \mathrm{~m} 3 /$ detik, kriteria normal adalah $0,045-0,217 \mathrm{~m} 3 /$ detik, dan untuk debit $\geq 0,218 \mathrm{~m} 3 /$ detik dapat dinyatakan basah.

\section{HUBUNGAN INDEKS KEKERINGAN SPI DENGAN DEBIT BULANAN}

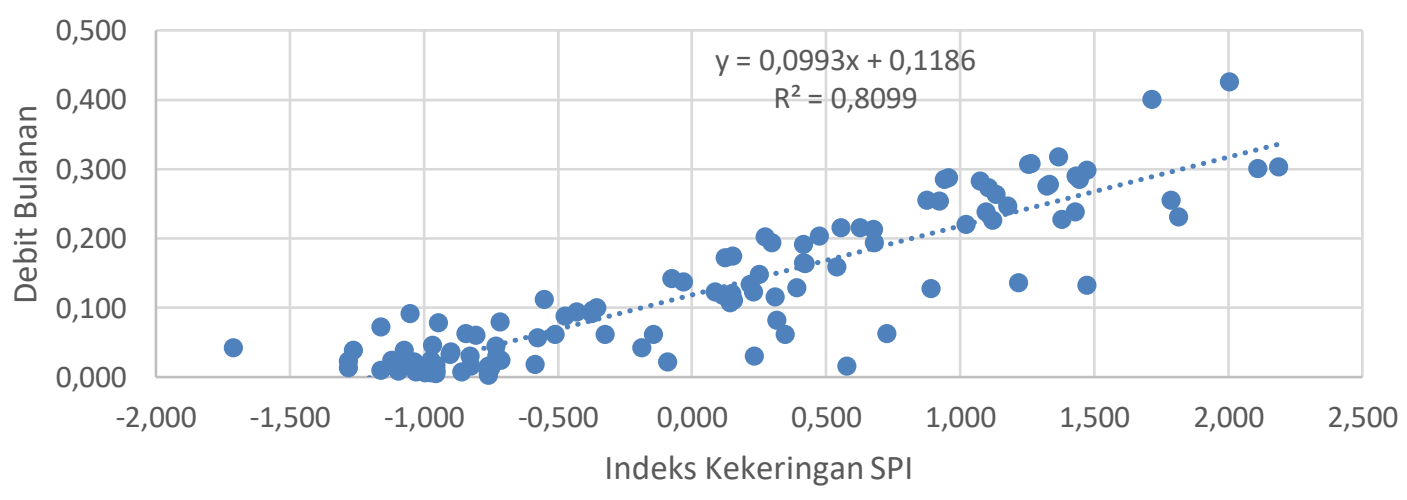

Gambar 3. Grafik Hubungan antara Indeks Kekeringan SPI dengan Debit Bulanan (Hasil Analisis)

Berdasarkan Gamber 3 dapat dijelaskan bahwa grafik yang terbentuk merupakan grafik linier dengan persamaan $\mathrm{y}=0,0993 x+0,1186$, dengan $y$ adalah debit bulanan dan $x$ adalah indeks kekeringan SPI. Untuk memastikan hasil dari rentang nilai debit adalah, maka dilakukan uji trial dengan menghitung nilai debit bulanan menggunakan persamaan yang didapatkan grafik. Dari hasil uji trial, maka keandalan dari nilai rentang debit yang didapatkan adalah $81,8 \%$.

\section{Pemetaan Persebaran Kriteria Kekeringan}


Pemetaan persebaran kriteria kekeringan dalam penelitian ini dianalisis menggunakan software ArcGIS. Pemetaan dalam penelitian ini hanya dilakukan pada kriteria normal, kering, sangat kering, dan amat sangat kering. Untuk membedakan kriteria digunakan warna yang berbeda untuk masing-masing kriteria.

Pada tahun 2008 dan 2009 tidak terjadi kekeringan di DAS Tirtomoyo. Namun, curah hujan sudah mulai berkurang dari bulan Juni dan Juli sampai bulan November dan Oktober. Sehingga, kekeringan terdeteksi pada tahun 2010 sampai dengan tahun 2014. Kekeringan tidak terjadi kembali pada tahun 2015. Namun, curah hujan sudah mulai berkurang dari bulan Mei sampai Oktober. Sehingga, kekeringan terdeteksi pada tahun 2016. Pada tahun 2016 kekeringan terjadi mulai dari bulan Mei dan terjadi sangat kering pada bulan Agustus. Begitu juga dengan tahun 2017 yang disajikan dalam Gambar 4, curah hujan mulai berkurang mulai dari bulan Mei dan berkurang ekstrem pada bulan Juli. Sehingga kekeringan terjadi mulai dari bulan Juli sampai bulan Agustus.

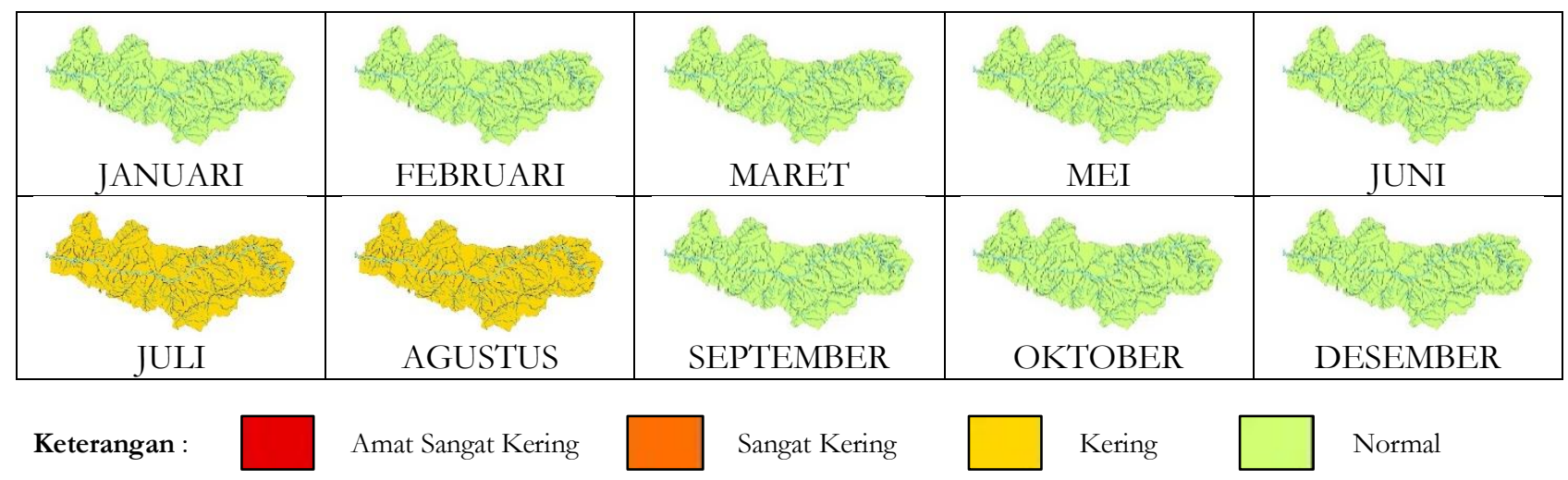

Gambar 4. Pemetaan Kriteria Kekeringan pada Tahun 2017

\section{SIMPULAN}

Debit bulanan GR2M di DAS Tirtomoyo didapatkan debit terkecil yaitu $0,002 \mathrm{~m}^{3} /$ detik pada November 2008 dan debit terbesar 0,426 m³/detik pada Februari 2009. Sedangkan indeks kekeringan SPI didapatkan indeks terkecil yaitu -1,71 dengan kriteria sangat kering pada Agustus 2016 dan indeks terbesar yaitu 2,19 dengan kriteria amat sangat basah pada Desember 2014. Dari hubungan indeks kekeringan dan debit bulanan didapatkan persamaan $y=0,0993 x+0,1186$ dan rentang debit sesuai dengan kriteria kekeringan sampai keandalan 81,8\%. Pemetaan kriteria kekeringan DAS Tirtomoyo menunjukkan bahwa kekeringan tidak terjadi pada seluruh bulan di tahun 2008, 2009 dan 2015, dan kekeringan terparah terjadi pada Agustus 2016.

\section{REKOMENDASI}

Penelitian ini hanya dilakukan dengan kurun waktu selama 10 tahun, sebaiknya dilanjutkan penelitian dengan kurun waktu lebih dari 10 tahun

\section{UCAPAN TERIMAKASIH}

Ucapan terima kasih pertama ditujukan kepada Allah SWT atas limpahan rahmat dan nikmatnya. Selanjutnya kepada Dr. Ir. Rr. Rintis Hadiani, M.T. dan Setiono, S.T., M.T. selaku dosen pembimbing yang telah memberi arahan dan masukan dalam penelitian ini.

\section{REFERENSI}

Bambang Triatmodjo. 2010. Hidrologi Terapan. Yogyakarta: Beta Offset

McKee, Thomas B. Doesken, Nolan J. \& Kleist, John. 1993. The Relationship Of Drought Frequency and Duration to Time Scales. Colorado: Department of Atmospheric Science.

Mouelhi, Safouane. Michel, Charles. Perrin, Charles and Andréassian. Vazken 2006. Stepwise Development of a Two Parameter Monthly Water Balance Model. Journal of Hydrology. Vol. 318. No. 1-4. 2006. pp. 200-214.

Nofriyadi Widodo. 2013. Analisis dan Pemetaan Indeks Kekeringan Meteorologis Menggunakan Data Staelit TRMM dari 36 Titik Stasiun BMKG di Pulau Sumatera (Skripsi). Bogor: Institut Pertanian Bogor.

Perrin, Charles. Michel, Claude. \& Andreassian, Vazken. 2007. Modeles Hydrologiques du Genie Rural (GR). France : Cemagref.

Rr Rintis Hadiani. 2009. Analisis Kekeringan Berdasarkan Data Hidrologi. Disertasi. Malang: Universitas Brawijaya. Sri Harto. 1993. Analisis Hidrologi. Jakarta: PT. Gramedia Pustaka Utama.

World Meteorological Organization. 2012. Standardized Precipitation Index User Guide. Switzerland. 